\title{
AKSI BOIKOT PAJAK MENURUT HUKUM ISLAM ${ }^{*}$
}

\author{
Arip Purkon ${ }^{1}$ \\ Permalink: https://www.academia.edu/9989758
}

\begin{abstract}
Tax Boycott According to Islamic law. Taxes are the largest source of state revenue. Budget development and government operations have a heavy reliance on taxes. However, in tax management is often found in cases involving criminal tax among other tax officials. This has led to the decline in public confidence in the tax administration and thus creating a discourse of boycott taxes. This tax boycott called by various groups, individuals, community leaders, Non Governmental Organizations (NGOs) to religious organizations. This paper discusses the boycott of the tax according to Islamic law. The first thing to be discussed is how the legality of the tax and the historical development of various charges in Islam. A study on the boycott taxes according to Islamic law is used mursalah mashlahah theory and sadd al-dzari'ah.
\end{abstract}

Keywords: Taxation, Islamic Law, Mashlahat, Sadd al-dzari'ah, State

Abstrak: Aksi Boikot Pajak Menurut Hukum Islam. Pajak merupakan sumber pendapatan negara terbesar. Anggaran pembangunan dan operasional pemerintahan mempunyai ketergantungan yang besar pada pajak. Namun dalam pengelolaan pajak seringkali ditemukan kasus pidana pajak yang melibatkan antara lain pegawai pajak. Hal ini menimbulkan turunnya kepercayaan publik terhadap pengelolaan pajak sehingga lahirlah wacana aksi boikot pajak. Aksi boikot pajak ini diserukan oleh berbagai kalangan, baik individu, tokoh masyarakat, Lembaga Swadaya Masyarakat (LSM) sampai organisasi keagamaan. Tulisan ini membahas aksi boikot pajak tersebut menurut hukum Islam. Hal pertama yang dibahas adalah bagaimana legalitas pajak dan sejarah perkembangan berbagai pungutan di dalam Islam. Kajian tentang aksi boikot pajak menurut hukum Islam ini menggunakan teori mashlahah mursalah dan sadd al-dzari'ah.

Kata Kunci: Pajak, Hukum Islam, Mashlahat, Sadd al-Dzari’ah, Negara

* Diterima tanggal naskah diterima: 12 Maret 2014, direvisi: 29 April 2014, disetujui untuk terbit: 10 Juni 2014.

${ }^{1}$ Fakultas Syariah dan Hukum UIN Syarif Hidayatullah Jakarta. Jl. Ir. Juanda No. 95 Ciputat, Jakarta. E-mail: arippurkon@gmail.com 


\section{Pendahuluan}

Pajak merupakan iuran rakyat kepada kas negara berdasarkan undangundang dengan tidak mendapat balas jasa secara langsung. Pajak dipungut oleh pemerintah berdasarkan norma-norma hukum untuk menutup biaya produksi barang-barang dan jasa kolektif untuk mencapai kesejahteraan umum. ${ }^{2}$ Di Indonesia, lembaga pemerintah yang mengelola perpajakan negara adalah Direktorat Jenderal Pajak yang merupakan salah satu direktorat jenderal yang ada di bawah naungan Kementerian Keuangan Republik Indonesia.

Secara umum, pajak yang berlaku di Indonesia dapat dibedakan menjadi pajak pusat dan pajak daerah. Pajak pusat adalah pajak-pajak yang dikelola oleh Pemerintah Pusat yang dalam hal ini sebagian dikelola oleh Direktorat Jenderal Pajak Departemen Keuangan. Sedangkan Pajak Daerah adalah pajak-pajak yang dikelola oleh Pemerintah Daerah, baik di tingkat Propinsi maupun Kabupaten atau Kota.

Pajak yang dikelola oleh Pemerintah Pusat antara lain Pajak Penghasilan (PPh), Pajak Pertambahan Nilai (PPN), Pajak Penjualan atas Barang Mewah (PPnBM), Bea Materai, Pajak Bumi dan Bangunan (PBB), Bea Perolehan Hak Atas Tanah dan Bangunan (BPHTB) dan yang lainnya. Adapun pajak yang dipungut oleh Pemerintah Daerah, dalam hal ini propinsi antara lain adalah Pajak Kendaraan Bermotor, Bea Balik Nama Kendaraan Bermotor dan yang lainnya. Pajak yang dipungut oleh Pemerintah Daerah Kabupaten/Kota antara lain pajak hotel, pajak restoran, pajak hiburan, pajak reklame, pajak parker dan yang lainnya.

Pajak mempunyai peranan yang sangat signifikan dalam kehidupan bernegara, khususnya di dalam pelaksanaan pembangunan karena pajak merupakan sumber pendapatan negara untuk membiayai sebagian pengeluaran termasuk pengeluaran pembangunan.

Seperti negara-negara lainnya, Indonesia masih mengenakan pajak terhadap warga negaranya. Tax rasio Indonesia masih tergolong cukup kecil, yaitu hanya berada di kisaran 12\%. Meskipun demikian, jumlah penerimaan pajak selalu mengalami peningkatan setiap tahun. Jika melihat komposisi penerimaan negara dalam Anggaran Pendapatan Belanja Negara (APBN), sejak tahun 2006 sampai 2011, sektor pajak dan bea cukai memberi kontribusi ratarata sebesar $70 \%$ dari total pendapatan negara. Dengan demikian maka tidak dapat dipungkiri bahwa sektor pajak merupakan sumber utama pembiayaan negara. Indonesia tampaknya belum siap untuk mengandalkan sektor lain selain sektor pajak. Dalam APBN tahun 2011, penerimaan dari sektor pajak mencapai Rp873.9 triliun, sedangkan penerimaan negara dari sektor Energi dan Sumber Daya Mineral (ESDM) sebesar Rp352 triliun. Meskipun terbilang cukup besar, penerimaan sektor ESDM ini belum mampu menutupi pengeluaran negara dan hanya memberi income sebesar $29,7 \%$ dari total penerimaan negara. ${ }^{3}$

\footnotetext{
${ }^{2}$ http://id.wikipedia.org/wiki/Pajak, diunduh tanggal 20 Maret 2013.

3 http://www.pajak.go.id/content/article/siapkah-membangun-negeri-ini-tanpa-pajak, diunduh tanggal 20 Maret 2013.
} 
Pada tahun 2012, Direktorat Jenderal Pajak (DJP) mencapai target penerimaan pajak sebesar $\mathrm{Rp}$ 872,6 triliun atau 99,3 persen dari target penerimaan perpajakan 2011. Tahun 2013 DJP menaikan target perpajakan menjadi Rp 1.032 triliun atau menyumbang 78 persen dari total penerimaan negara. ${ }^{4}$

Pada tahun 2009, Direktorat Jenderal Pajak (DJP) mensinyalir potensi penyelewengan pembayaran pajak perusahaan-perusahaan besar yang kian marak. Modus yang digunakan antara lain adalah merekayasa keuangan perusahaan dengan melaporkan penurunan laba perusahaan. Selain itu, banyak kasus penyelewengan atau korupsi yang dilakukan oleh oknum pegawai pajak. Sebagian besar dari kasus tersebut seakan-akan menggantung tanpa ada sanksi yang jelas dan tegas. Hal ini mempunyai dampak yang kurang baik di masyarakat.

Musyawarah Nasional (Munas) Nahdhatul Ulama tahun 2012 di Cirebon merekomendasikan antara lain persoalan pajak. Dalam rekomendasinya disebutkan bahwa bagi umat Islam, pungutan yang wajib dibayar berdasarkan perintah langsung dari Alquran dan Hadits secara eksplisit adalah zakat. Sedangkan kewajiban membayar pajak hanya berdasarkan perintah yang tidak langsung (implicit) dalam konteks mematuhi penguasa (ulil 'amri), Penguasa di dalam membelanjakan uang negara yang diperoleh dari pajak berdasarkan kaidah fikih "tasharruf al-imam 'ala ra'iyyah manuth bi almashlahah al-raiyyah", mesti mengacu pada tujuan kesejahteraan dan kemanusiaan warga negara (terutama kaum fakir miskin). Ketika ternyata bahwa uang negara yang berasal dari pajak tidak dikelola dengan baik atau tidak dibelanjakan sebagaimana mestinya bahkan terbukti banyak dikorupsi, maka muncul pertanyaan: apakah kewajiban membayar pajak oleh warga negara itu masih punya landasan hukum keagamaan yang kuat? atau masihkah menjadi wajib membayar pajak tersebut?

Atas dasar hal ini maka Munas NU tahun 2012 merekomendasikan: (1) Pemerintah harus lebih transparan dan bertanggungjawab terkait dengan penerimaan dan pengalokasian uang pajak, serta memastikan tidak ada kebocoran. (2) Pemerintah harus mengutamakan kemaslahatan warga negara terutama fakir miskin dalam penggunaan pajak. (3) PBNU perlu mengkaji dan mempertimbangkan mengenai kemungkinan hilangnya kewajiban warga negara membayar pajak ketika pemerintah tidak dapat melaksanakan rekomendasi kedua poin di atas 5 .

Wacana aksi boikot pajak ini terus berkembang dan menimbulkan prokontra di masyarakat. Sebagian kalangan menganggap bahwa tindakan memboikot pajak akan sangat merugikan negara. Namun ada juga yang berpendapat bahwa aksi tersebut merupakan akumulasi kekecewaan masyarakat

\footnotetext{
${ }^{4}$ http://www.republika.co.id/berita/nasional/umum/12/03/19/m14q3y-targetpenerimaan-pajak-meningkat, diunduh tanggal 22 Maret 2013.

5 http://www.nu.or.id/a,public-m,dinamic-s, detail-ids,6-id,39821-lang,id-c,taushiyaht, Inilah+4+Rekomendasi+Hasil+Munas+NU-.phpx, diunduh tanggal 20 Maret 2013.
} 
dan menjadi peringatan bagi pemerintah untuk memperbaiki pengelolaan dan pemungutan pajak.

\section{Konsep Dasar Pajak}

Prof. Dr. Rochmat Soemitro, SH mendefinisikan pajak sebagai iuran rakyat pada kas negara berdasarkan undang-undang yang bersifat memaksa dengan tidak mendapat jasa imbalan (kontra prestasi), yang langsung dapat ditunjukkan dan digunakan untuk membayar pengeluaran umum (public investment). ${ }^{6}$ Adapun Sommerfield memberikan definisi pajak sebagai suatu pengalihan sumber-sumber yang wajib dilakukan dari sektor swasta pada sektor pemerintah berdasarkan peraturan tanpa mendapat suatu imbalan kembali yang langsung dan seimbang, agar pemerintah dapat melaksanakan tugas-tugasnya menjalankan pemerintahan.

Selain itu, berikut ini adalah beberapa pengertian tentang pajak yang dikemukakan oleh para ahli: ${ }^{8}(1)$ Menurut P. J. A. Adriani, pajak adalah iuran masyarakat pada negara (yang dapat dipaksakan) yang terutang oleh yang wajib membayarnya menurut peraturan-peraturan umum (undang-undang) dengan tidak mendapat prestasi kembali yang langsung dapat ditunjuk dan yang gunanya adalah untuk membiayai pengeluaran-pengeluaran umum berhubung tugas negara untuk menyelenggarakan pemerintahan; (2) Menurut Leroy Beaulieu, pajak adalah bantuan, baik secara langsung maupun tidak yang dipaksakan oleh kekuasaan publik dari penduduk atau dari barang, untuk menutup belanja pemerintah; (3) Menurut Anderson Herschel M., \& Brock Horace R, pajak adalah suatu pengalihan sumber dari sektor swasta ke sektor pemerintah, bukan akibat pelanggaran hukum, namun wajib dilaksanakan, berdasarkan ketentuan yang ditetapkan lebih dahulu, tanpa mendapat imbalan yang langsung dan proporsional, agar pemerintah dapat melaksanakan tugastugasnya untuk menjalankan pemerintahan.

Dari perspektif ekonomi, pajak dapat dipahami sebagai beralihnya sumber daya dari sektor privat pada sektor publik. Pemahaman ini memberikan gambaran bahwa adanya pajak menyebabkan dua situasi menjadi berubah, yaitu; (1) Berkurangnya kemampuan individu dalam menguasai sumber daya untuk kepentingan penguasaan barang dan jasa, (2) Bertambahnya kemampuan keuangan negara dalam penyediaan barang dan jasa publik yang merupakan kebutuhan masyarakat.

Sementara pemahaman pajak dari perspektif hukum menurut Soemitro merupakan suatu perikatan yang timbul karena adanya undang-undang yang menyebabkan timbulnya kewajiban warga negara untuk menyetorkan sejumlah penghasilan tertentu kepada negara. Negara mempunyai kekuatan untuk

${ }^{6}$ Wirawan B. Ilyas dan Richard Burton, Hukum Pajak (Jakarta: Salemba Empat, edisi 3, 2007), h. 5. dan Soemarso, Perpajakan Pendekatan Komprehensif (Jakarta: Salemba Empat, 2007), h. 2-3.

7 Majalah Prisma, LP3ES, 1985, h. 1. Lihat juga Kesit Bambang Prakosa, Hukum Pajak (Yogyakarta: EKONISIA, 2005, h. 2.

${ }^{8}$ Http://id.wikipedia.org/wiki/Pajak, diakses tanggal 1 Oktober 2013. 
memaksa dan uang pajak tersebut harus dipergunakan untuk penyelenggaraan pemerintahan. Dari pendekatan hukum ini memperlihatkan bahwa pajak yang dipungut harus berdasarkan undang-undang, sehingga menjamin adanya kepastian hukum, baik bagi fiskus sebagai pengumpul pajak maupun wajib pajak sebagai pembayar pajak.

Menurut UU No 28 Tahun 2007, pasal 1, pajak adalah kontribusi wajib kepada negara yang terutang oleh orang pribadi atau badan yang bersifat memaksa berdasarkan Undang-Undang dengan tidak mendapatkan imbalan secara langsung dan digunakan untuk keperluan negara bagi sebesar-besarnya untuk kemakmuran rakyat.'

Berdasarkan pengertian tersebut, maka ciri-ciri pajak adalah; (1) Pajak adalah pengalihan sumber-sumber dari sektor swasta ke sektor negara, artinya bahwa yang berhak melakukan pemungutan pajak adalah negara, baik pemerintah pusat maupun pemerintah daerah (Pemda). Di Indonesia, Pemda yang berwenang memungut pajak adalah pemerintah propinsi maupun pemerintah Kabupaten/Kota. Sedangkan yang dipungut adalah pihak swasta dalam pengertian luas baik sektor swasta, koperasi, BUMN, BUMD dan lainlain. Secara konsep pajak dapat dibayar dengan uang maupun barang atau jasa selain uang; (2) Berdasarkan UU, artinya bahwa walaupun negara mempunyai hak untuk memungut pajak namun pelaksanaannya harus memperoleh persetujuan dari wakil-wakil rakyat dengan menyetujui UU. Karena pemungutan pajak berdasarkan UU, maka berarti bahwa pemungutan pajak dapat dipaksakan; (3) Tanpa imbalan dari negara yang langsung dapat ditunjuk secara individual, artinya bahwa imbalan tersebut tidak dikhususkan bagi rakyat secara individual dan tidak dapat dihubungkan secara langsung dengan besarnya pajak. Imbalan dari negara kepada rakyat sifatnya tidak langsung; (4) Untuk membiayai pengeluaran pemerintah baik pengeluaran rutin maupun pengeluaran pembangunan. ${ }^{10}$

Hukum pajak adalah kumpulan peraturan yang mengatur hubungan antara pemerintah dengan rakyat atau wajib pajak. Pemerintah sebagai pemungut pajak dan wajib pajak atau rakyat sebagai pembayar pajak. Hukum pajak sering disebut hukum fiskal. Pemerintah sebagai pemungut dan administratur pajak disebut dengan Fiskus. Hukum pajak dapat dibagi menjadi dua macam; yaitu hukum pajak materil dan hukum pajak formil. ${ }^{91}$ Hukum pajak materiel adalah hukum pajak yang memuat norma-norma tentang; (1) Objek pajak, yaitu objek apa yang dikenakan pajak. Objek pajak sering disebut tatsbestand; (2) Subjek pajak yaitu siapa yang dikenakan pajak; (3) Tarip pajak; (4) Sanksi-sanksi dalam hubungan hukum antara pemerintah dengan wajib pajak. Hukum pajak formil adalah hukum pajak yang memuat cara-cara untuk mewujudkan hukum pajak materil menjadi suatu kenyataan atau realisasi. Hukum pajak formil antara lain memuat; (1) Tata cara (prosedur) penetapan

${ }^{9}$ UU No 28 Tahun 2007, pasal 1.

${ }^{10}$ Kesit Bambang Prakosa, Hukum Pajak (Yogyakarta: Ekonisia, 2005), h.3 dan Waluyo, Perpajakan Indonesia. (Jakarta: Penerbit Salemba Empat, 2006), h. 3.

${ }^{11}$ Kesit Bambang Prakosa, Hukum Pajak, h.v. 
jumlah utang pajak;(2) Hak-hak fiskus untuk mengadakan monitoring dan pengawasan;(3) Kewajiban mengadakan pembukuan atau pencatatan; (4) Prosedur pengajuan surat keberatan, banding dan sebagainya.

Pokok-pokok produk hukum nasional yang mengatur tentang perpajakan antara lain adalah sebagai berikut:

1. Undang-Undang No. 36 Tahun 2008 tentang Perubahan Keempat atas Undang-Undang Nomor 7 Tahun 1983 tentang Pajak Penghasilan;

2. Undang-undang No. 28 Tahun 2007 Tentang Ketentuan Umum Perpajakan. Perubahan terhadap UU No. 6 Tahun 1983;

3. Undang-undang No. 12 Tahun 1985 tentang pajak bumi dan bangunan;

4. UU Nomor 42 Tahun 2009 tentang Perubahan Ketiga atas UU Nomor 8 Tahun 1983 tentang pajak pertambahan nilai barang dan jasa dan pajak penjualan atas barang mewah;

5. UU Nomor 21 Tahun 1997 tentang bea perolehan hak atas tanah dan/atau bangunan (telah diamandemen menjadi UU Nomor 20 Tahun $2000 .^{12}$

Untuk kelengkapan terkait peraturan perundang-udangan baik berbentuk UU maupun PP dapat dilihat di website http://www.pajakonline.com/ dan http://www.pajak.go.id/.

Fungsi pajak dibagi menjadi dua, yaitu: fungsi budgetair atau fungsi finansial dan fungsi redistribusi pendapatan bagi masyarakat. Fungsi budgetair, sebagaimana halnya perekonomian dalam suatu keluarga, perekonomian negara juga mengenal sumber-sumber penerimaan dan pos-pos pengeluaran. Pajak merupakan sumber utama penerimaan negara. Tanpa pajak, sebagian besar kegiatan negara sulit untuk dapat dilaksanakan. Penggunaan uang pajak meliputi belanja pegawai sampai dengan pembiayaan berbagai proyek pembangunan. Pembangunan sarana umum seperti jalan, jembatan, sekolah, rumah sakit, puskesmas, kantor pemerintahan dan yang lainnya dibiayai dengan menggunakan uang yang berasal dari pajak. Uang pajak juga digunakan untuk pembiayaan dalam rangka memberikan rasa aman bagi seluruh lapisan masyarakat. Setiap warga negara mulai saat dilahirkan sampai dengan meninggal dunia menikmati fasilitas atau pelayanan dari pemerintah yang semuanya dibiayai dengan uang yang berasal dari pajak. Dengan demikian jelas bahwa peranan penerimaan pajak bagi suatu negara menjadi sangat dominan dalam menunjang jalannya roda pemerintahan dan pembiayaan pembangunan. ${ }^{13}$

Disamping fungsi budgetair (fungsi penerimaan), pajak juga melaksanakan fungsi regulered atau fungsi mengatur yaitu fungsi pajak untuk mengatur sesuatu keadaan di masyarakat di bidang sosial, ekonomi atau politik sesuai dengan kebijaksanaan pemerintah. Oleh karena itu tingkat kepatuhan wajib pajak dalam melaksanakan kewajiban perpajakannya secara baik dan

12 http://www.pajakonline.com/engine/learning/index_cat.php?id=226, diakses Oktober 2013.

${ }^{13}$ Buku Panduan Hak dan Kewajiban Perpajakan, diterbitkan dalam bentuk e-book oleh Dirjen Pajak Kemenkeu RI, http: www.pajakonline.com, diakses 1 Oktober 2013. 
benar merupakan syarat mutlak untuk tercapainya fungsi ini, sehingga pada akhirnya diharapkan kesenjangan ekonomi dan sosial yang ada dalam masyarakat dapat dikurangi secara maksimal. ${ }^{14}$

\section{Jenis-Jenis Pungutan dalam Islam}

Kegiatan ekonomi Islam bermula ketika Nabi Muhammad Saw diutus menjadi seorang Rasul atau utusan Allah. Rasulullah Saw mengajarkan sekaligus mencontohkan berbagai hal yang berkaitan dengan masalah kemasyarakatan, hukum, politik, dan juga masalah ekonomi. Masalah ekonomi menjadi salah satu pusat perhatian utama Rasulullah Saw, karena ekonomi merupakan salah satu pilar penyangga keimanan yang penting. ${ }^{15}$ Upaya mengentaskan kemiskinan merupakan salah satu kebijakan sosial yang dikeluarkan Rasulullah Saw. Lebih dari itu, Rasulullah Saw juga sangat memperhatikan keadaan ekonomi umat Islam. Masjid dijadikan sebagai pusat peradaban dan kebudayaan Islam. Selain sebagai pusat ibadah, Rasulullah Saw juga memfungsikan masjid sebagai pusat pemerintahan, militer dan pusat perekonomian. ${ }^{16}$

Pada saat awal dideklarasikan Madinah sebagai sebuah negara, Madinah hampir tidah memiliki sumber pemasukan ataupun pengeluaran negara. Seluruh tugas negara dilaksanakan oleh kaum muslim secara bergotong royong dan sukarela. Mereka memperoleh pendapatan dari berbagai sumber yang tidak terikat. Oleh karena itu, Madinah merupakan negara yang baru dibentuk dengan kemampuan daya mobilitas yang sangat rendah dari sisi ekonomi. Karena peletakan dasar-dasar sistem keuangan negara yang dilakukan oleh Rasulullah Saw merupakan langkah yang sangat signifikan dan sprektakuler pada masa itu. Islam menjadi agama dan negara yang dapat berkembang dengan pesat dalam jangka waktu yang relatif singkat. Dalam perjalanan roda pemerintahannya, Rasulullah Saw mendapat 2 sumber pendapatan secara umum, yaitu: sumber pendapatan primer dan sumber pendapatan sekunder. ${ }^{17}$

Sumber pendapatan primer merupakan pendapatan utama bagi negara yaitu berupa zakat dan ushur. Keduanya berbeda dengan pajak dan tidak diperlakukan seperti pajak. Zakat dan ushur merupakan kewajiban agama dan termasuk salah satu pilar Islam. Dan pengeluaran untuk zakat tidak dapat dibelanjakan untuk pengeluaran umum negara. Lebih jauh lagi, zakat secara fundamental adalah pajak lokal. Dalam sesuatu hadits diriwayatkan bahwa Rasulullah Saw berkata kepada Muadz, ketika ia mengirimnya ke Yaman sebagai pengumpul dan pemberi zakat: "Katakanlah kepada penduduk Yaman bahwa Allah telah mewajibkan mereka untuk membayar zakat yang akan

\footnotetext{
${ }^{14}$ Simon James and Christopher Nobes, The Economics of Taxation, (Edinburgh: Pearson Educatioan Limited. ed. 7. 2003), h. 10.

${ }^{15}$ Adiwarman Azwar Karim, Sejarah Pemikiran Ekonomi Islam, (Jakarta: The International Institue of Islamic Thought Indonesia (IIIT), 2001), h.19-20.

${ }_{17}^{16}$ Adiwarman Azwar Karim, Sejarah Pemikiran Ekonomi Islam, h.21.

${ }^{17}$ P3EI UII Yogyakarta, Ekonomi Islam (Jakarta: Rajawali Press, 2008), h.98-99.
} 
diambil dari orang kaya di antara mereka, dan memberikannya kepada orang miskin di antara mereka." Dari sini dapat dipahami bahwa pemerintah pusat berhak menerima keuntungan hanya apabila terjadi surplus yang tidak dapat didistribusikan lagi kepada orang-orang yang berhak. Pencatatan seluruh penerimaan negara pada masa Rasulullah Saw tidak ada. Dalam kebanyakan kasus pencatatan diserahkan pada pengumpul zakat, karena setiap orang pada umumnya telah terlatih dalam masalah pengumpulan zakat. ${ }^{18}$

Di samping sumber-sumber pendapatan primer sebagai penerimaan fiskal pemerintahan Rasulullah Saw, ada juga sumber pendapatan sekunder yang menjadi sumber pendapatan Negara, antara lain: (1) Uang tebusan untuk para tawanan perang. Hal ini hanya khusus pada perang Badar. Sementara pada perang lain tidak disebutkan jumlah uang tebusan tawanan perang; (2) Pinjaman-pinjaman setelah menaklukkan kota Makkah, untuk pembayaran uang pembebesan kaum muslimin dari Judhaima atau sebelum pertempuran Hawazin sebesar 20.000 atau 30.000 dirham dan meminjam beberapa pakaian dan hewan tunggangan dari Sofyan bin Umaiyah; (3) Khums atas rikaz atau harta karun temuan pada periode sebelum Islam; (4) Amwal fadhilah yaitu harta yang berasal dari harta benda kaum muslim yang meninggal tanpa ahli waris, atau berasal dari barang-barang seorang muslim yang meninggalkan negerinya; (5) Wakaf adalah harta benda yang didedikasikan oleh seorang muslim untuk kepentingan agama Allah dan pendapatannya disimpan di Baitul mal; (6) Nawaib adalah pajak khusus yang dibebankan kaum muslimin yang kaya raya dalam rangka menutupi pengeluaran negara selama masa darurat; (7) Jizyah yaitu pajak yang dibebankan kepada orang-orang non muslim; (8) Kharaj, yaitu pajak tanah yang dipunggut dari kaum non muslim ketika wilayah Khaibar ditaklukkan; (9) Zakat fitrah, yaitu zakat yang ditarik di bulan Ramadhan dan dibagikan sebelum sholat idul fitri; (10) Shadaqah, seperti kurban dan kaffarat. Kaffarat adalah denda atas kesalahan yang dilakukan seorang muslim pada acara keagamaan, seperti berburu di musim haji; (11) Ghanimah atau harta rampasan perang atas musuh yang kalah; (12) Fay' atau harta yang ditinggalkan oleh pemiliknya tanpa peperangan. ${ }^{19}$

Mesjid Nabawi mempunyai fungsi selain untuk beribadah juga digunakan sebagai kantor pemerintahan, tempat tinggal Rasulullah Saw dan juga baitul mal. Sementara harta negara berupa binatang-binatang tidak bisa disimpan di baitul mal akan tetapi ditempatkan di lapangan terbuka. Pemasukan yang diterima negara disimpan di mesjid dalam jangka waktu yang singkat, untuk kemudian didistribusikan kepada masyarakat yang membutuhkan tanpa ada sisa. Sejarah mencatat kurang lebih terdapat 40 sahabat yang dapat dikatakan sebagai pegawai Rasulullah, namun tidak disebutkan adanya seorang bendahara negara. Karena hal ini hanya dimungkinkan terjadi di dalam lingkungan yang memiliki pengawasan yang ketat.

\footnotetext{
${ }^{18}$ P3EI UII Yogyakarta, Ekonomi Islam, h.98-99.

${ }^{19}$ P3EI UII Yogyakarta, Ekonomi Islam, h.99.
} 
Setelah Rasulullah Saw wafat dan pemerintahan berada di tangan Abu Bakar al-Shiddiq belum banyak perubahan dan inovasi baru yang berkaitan dengan sektor ekonomi dan keuangan negara. Kondisinya masih seperti pada masa Rasulullah Saw. Kondisi dapat dipahami karena pada masa pemerintahannya konsentrasi Abu Bakar terfokus pada masalah untuk mempertahankan eksistensi Islam dan kaum muslimin. Disamping itu para sahabat masih terfokus untuk memerangi mereka yang tidak mau membayar zakat setelah wafatnya Rasulullah Saw, dan memerangi kelompok orang yang murtad serta munculnya beberapa nabi palsu. ${ }^{20}$ Abu Bakar al-Shiddiq terpilih sebagai khalifah dalam kondisi tidak begitu kaya secara materi. Agar lebih fokus menangani urusan kaum muslimin, sejak menjadi khalifah kebutuhan pokok keluarga Abu Bakar ditanggung oleh baitul maal. Di akhir masa kekhalifahannya dan mendekati wafatnya, sumber pendapatan negara semakin menipis. Hal ini menyebabkan kekayaan pribadinya dipergunakan untuk pembiayaan negara. ${ }^{21}$

Setelah Abu Bakar RA wafat, pemerintahan beralih ke tangan Umar bin Khattab. Beliau banyak melakukan perluasan kekuasaan Islam hingga ke wilayah di jazirah arab, sebagian wilayah Romawi yaitu Syria, Palestina dan Mesir, serta seluruh kerajaaan Persia, termasuk Irak. Umar bin Khaththab banyak mencotoh Persia dalam mengatur administrasi negara. Untuk masalah kebijakan keuangan, Khalifah Umar banyak melakukan perubahan, diantaranya adalah baitul maal, kepemilikan tanah, zakat dan ushur, sedekah untuk non muslim dan mata uang. Pembangunan baitul maal di zaman khalifah Umar dilatarbelakangi oleh kedatangan Abu Hurairah (Gubernur Bahrain saat itu) dengan membawa harta hasil pengumpulan pajak sebesar 500.000 dirham. Dan inisiatif Khalifah Umar adalah untuk tidak mendistribusikan harta yang ada di baitul maal, tetapi disimpan sebagai cadangan untuk keperluan darurat, membiayai gaji para tentara dan keperluan umat lainnya. Harta yang tersimpan di baitul maal merupakan harta umat Islam. Adapun khalifah dan amil-amilnya hanyalah pemegang kepercayaan untuk mengatur penerimaan dan pendistribusian terhadap umat yang membutuhkan, seperti para janda, anak yatim, anak terlantar, orang faqir dan miskin, membayar hutang orang bangkrut dan gaji bagi penyebar dakwah Islam.

Pada masa pemerintahan Umar bin Khaththab, banyak daerah yang ditaklukkan melalui perjanjian damai. Dari sinilah mulai muncul permasalahan bagaimana cara pembagiannya. Beberapa sahabat ada yang menuntut untuk mendistribusikan kekayaan itu dan sebagian lainnya menolaknya. Maka dari itu, Khalifah Umar mencari solusi dari masalah ini dengan melakukan musyawarah, dengan keputusan untuk memperlakukan tanah-tanah tersebut sebagai fay, dan prinsip ini akan menjadi ketetapan untuk kasus-kasus yang akan datang. ${ }^{22}$

\footnotetext{
${ }^{20}$ P3EI UII Yogyakarta, Ekonomi Islam, h.101-102.

${ }_{21}^{21}$ P3EI UII Yogyakarta, Ekonomi Islam, h.102.

${ }^{22}$ P3EI UII Yogyakarta, Ekonomi Islam, h.102.
} 
Pada masa Khalifah Umar zakat dibebankan pada barang-barang yang memiliki sifat produktif, sehingga seorang budak atau seekor kuda yang dimiliki kaum muslimin ketika itu tidak dikenakan zakat. Karena maraknya perdagangan kuda, sebagian pedagang mengajukan permohonan kepada Khalifah Umar supaya diberlakukan zakat untuk kuda, sehingga ditetapkanlah zakat kuda sebesar satu dinar. Dan ushur dibebankan kepada suatu barang yang wajib dibayar hanya sekali dalan setahun, yaitu sebesar sepuluh persen dari nilai barang. Khalifah Umar menetapkan pajak pembelian 2,5\% untuk pedagang muslim, 5\% untuk kafir dzimmi dan 10\% untuk kafir harbi.

Tidak ada ahli kitab yang membayar sedekah atas ternaknya kecuali orang Kristen Bani Taghlib yang keseluruhan kekayaannya terdiri dari hewan ternak. Mereka membayar dua kali lipat dari yang dibayar kaum muslimin. Umar mengenakan jizyah kepada ahli kitab Bani Taghlib, tetapi mereka terlalu gengsi sehingga menolak membayar jizyah dan malah membayar sedekah. Nu'man ibn Zuhra memberikan alasan untuk kasus mereka dengan mengatakan bahwa pada dasarnya tidak bijaksana memperlakukan mereka seperti musuh dan seharusnya keberanian mereka menjadi aset negara. Umar menerima sedekah dua kali lipat dengan syarat mereka tidak boleh membaptis seorang anak atau memaksanya menerima kepercayaan mereka ${ }^{23}$.

Setelah Umar bin Khaththab wafat, pemerintahan dipegang Utsman bin Affan. Pada enam tahun pertama kepemimpinannya, Balhk, Kabul, Ghazni dan Karman ditaklukkan. Untuk menata pendapatan baru, kebijakan Umar tetap diakui dan diterapkan. Tidak lama setelah negara-negara itu ditaklukkan, tindakkan efektif langsung diterapkan dalam rangka pengembangan sumber daya alam. Pembuatan saluran alir untuk irigasi, pembangunan jalan, penanaman pohon buah-buahan dan pembentukkan pasukan keamanan segera dilaksanakan. Khalifah Utsman tidak mengambil upah dari kantornya, bahkan beliau meringankan beban pemerintahan dalam beberapa hal. Beliau menyimpan uang pribadinya di bendahara negara. Selain itu, khalifah Utsman juga selalu mendiskusikan fluktuasi harga yang sedang berlaku di pasaran dengan seluruh umat muslim setiap selesai sholat berjamaah di masjid. ${ }^{24}$

Setelah meninggalnya Utsman, Ali bin Abi Thalib terpilih sebagai khalifah yang keempat. Ali menjadi khalifah selama lima tahun. Kehidupan Ali sangat sederhana dan dia sangat ketat dalam menjalankan keuangan negara. Beliau mengambil beberapa kebijakan antara lain memberhentikan para pejabat yang korup, membuka kembali lahan perkebunan yang telah diberikan kepada orang-orang 'kesayangan' Khalifah Utsman, dan mendistribusikan pendapatan pajak tahunan sesuai dengan ketentuan yang ditetapkan Umar Bin Khattab. Beliau secara sukarela menarik diri dari daftar penerima bantuan baitul maal bahkan Ali memberikan sumbangan sebesar 5000 dirham setiap tahunnya. Khalifah Ali menetapkan pajak terhadap pemilik hutan sebesar 4000 dirham dan memungut pajak terhadap sayuran segar yang akan dibuat bumbu makanan.

\footnotetext{
${ }^{23}$ P3EI UII Yogyakarta, Ekonomi Islam, h.103.

${ }^{24}$ P3EI UII Yogyakarta, Ekonomi Islam, h.104.
} 
Khalifah Ali menginginkan pendistribusian seluruh pendapatan yang ada di baitul maal. Hal ini berbeda dengan Khalifah Umar dengan kebijakannya menyimpan sebagian untuk cadangan. Prinsip utama dari pemerataan distribusi uang rakyat telah diperkenalkan, yaitu hari kamis mendistribusikan dan hari sabtu dimulai penghitungan baru. Ali memiliki konsep yang jelas tentang pemerintahan, administrasi umum yang ditulis dalam sebuah surat yang isinya tentang bagaimana berhubungan dengan masyarakat sipil, lembaga peradilan dan angkatan perang. Khalifah Ali menekankan perhatian kesejahteraan para prajurit dan keluarganya, berkomunikasi langsung dengan masyarakat melalui pertemuan terbuka terutama orang-orang miskin, teraniaya dan penyandang cacat, melawan korupsi dan penindasan, mengontrol pasar, memberantas para tukang catut laba, penimbun barang dan pasar gelap. ${ }^{25}$

\section{Legalitas Pajak Menurut Hukum Islam}

Ulama berbeda pendapat tentang apakah ada kewajiban bagi kaum muslimin atas harta mereka selain zakat. Mayoritas ulama berpendapat bahwa zakat adalah satu-satunya kewajiban kaum muslim atas harta. Barang siapa yang telah menunaikan zakat, maka bersihlah hartanya dan terbebaslah dari kewajibannya. Dasarnya adalah berbagai hadis Rasulullah. ${ }^{26}$ Di sisi lain ada pendapat ulama bahwa dalam harta kekayaan ada kewajiban lain selain zakat. Jalan tengah dari dua perbedaan pendapat ini adalah bahwa kewajiban atas harta yang wajib adalah zakat, namun jika datang kondisi yang menghendaki adanya keperluan tambahan (darurah), maka akan ada kewajiban tambahan lain berupa pajak (dharibah). Pendapat ini misalnya dikemukakan oleh Qadhi Abu Bakar Ibn al-Arabi, Imam Malik, Imam Qurtubi, Imam Syatibi, Mahmud Syaltut, dan yang lainnya. ${ }^{27}$

Kebolehan memungut pajak menurut para ulama tersebut, alasan utamanya adalah untuk kemaslahatan umat, karena dana pemerintah tidak mencukupi untuk membiayai berbagai pengeluaran, yang jika pengeluaran itu tidak dibiayai, maka akan timbul kemudharatan. Sedangkan mencegah kemudaratan adalah juga suatu kewajiban. Sebagaimana kaidah ushul fiqh: $M a$ laa yutimmul wajib illa bihi fahuwa wajib (Sesuatu yang menyampaikan pada yang wajib maka hukumnya wajib). Oleh karena itu maka pajak tidak boleh dipungut se cara paksa dan kekuasaan semata, melainkan karena ada kewajiban kaum muslimin yang dibebankan pada negara, seperti memberi rasa aman, biaya kesehatan dan pendidikan dengan pengeluaran seperti nafkah untuk para tentara, gaji pegawai, hakim, dan lain sebagainya. Oleh karena itu, pajak memang merupakan kewajiban warga negara dalam sebuah negara muslim, dimana negara berkewajiban pula untuk memenuhi dua kondisi (syarat); (1) Penerimaan hasl-hasil pajak harus dipandang sebagai amanah dan dibelanjakan

${ }^{25}$ P3EI UII Yogyakarta, Ekonomi Islam, h.104.

${ }^{26}$ Antara lain hadits bahwa Rasulullah Saw ditanya"Apakah ada kewajiban lain di luar zakat? Nabi menjawab,"Tidak ada, kecuali shadaqah sunnah". (Hadits riwayat Bukhari dan Muslim).

${ }^{27}$ Gusfahmi, Pajak Menurut Syariah, (Jakarta: Rajawali Press, 2007), h. 169-181. 
secara jujur dan efisien untuk merealisasikan tujuan-tujuan pajak; (2) Pemerintah harus mendistribusikan beban pajak secara merata di antara mereka yang wajib membayarnya. ${ }^{28}$

Para ulama yang berpendapat diperbolehkannya memungut pajak menegaskan bahwa yang mereka maksud adalah sistem perpajakan yang adil, yang selaras dengan spirit Islam. Sistem perpajakan yang adil adalah apabila memenuhi tiga criteria; (1) Pajak dikenakan untuk membiayai pengeluaran yang benar-benar diperlukan untuk merealisasikan maqashid syariah; (2) Beban pajak tidak boleh terlalu kaku dan harus disesuaikan dengan kemampuan rakyat untuk menanggung dan pajak didistribusikan secara merata terhadap semua orang yang mampu membayar; (3) Dana pajak yang terkumpul dibelanjakan secara jujur bagi tujuan yang telah ditetapkan. ${ }^{29}$

Dalam istilah bahasa Arab, pajak dikenal dengan nama al-dharibah, ${ }^{30}$ yang artinya adalah beban. Pajak disebut beban karena merupakan kewajiban tambahan atas harta setelah zakat, sehingga dalam pelaksanaannya akan dirasakan sebagai sebuah beban. Baik secara bahasa maupun tradisi, dharibah dalam penggunaannya mempunyai banyak arti, namun para ulama memakai ungkapan dharibah untuk menyebut harta yang dipungut sebagai kewajiban dan menjadi salah satu sumber pendapatan negara. Sedangkan kharaj adalah berbeda dengan dharibah, karena kharaj adalah pajak yang obyeknya adalah tanah dan subyeknya adalah non-muslim. Sementara jizyah obyeknya adalah jiwa dan subyeknya adalah non-muslim. ${ }^{31}$

Pajak menurut Yusuf al-Qaradhawi adalah kewajiban yang ditetapkan terhadap wajib pajak, yang harus disetorkan kepada negara sesuai dengan ketentuan, tanpa mendapat prestasi kembali dari negara, dan hasilnya untuk membiayai pengeluran-pengeluaran umum di satu pihak dan untuk merealisasi sebagian tujuan ekonomi, sosial, politik dan tujuan-tujuan lain yang ingin dicapai oleh negara. ${ }^{32}$ Gazi Inayah berpendapat bahwa pajak adalah kewajiban untuk membayar tunai yang ditentukan oleh pemerintah atau pejabat berwenang yang bersifat mengikat tanpa adanya imbalan tertentu. Ketentuan pemerintah ini sesuai dengan kemampuan si pemilik harta dan dialokasikan untuk mencukupi kebutuhan pangan secara umum dan untuk memenuhi tuntutan politik keuangan bagi pemerintah. ${ }^{33}$

Abdul Qadim berpendapat pajak adalah harta yang diwajibkan Allah SWT kepada kaum muslim untuk membiayai berbagai kebutuhan dan pos-pos

${ }^{28}$ Umer Chapra, Islam and The Economic challenge, (Herndon: IIIT, 1995). Diterjemahkan oleh Ikhwan Abidin Basri, Islam dan Tantangan Ekonomi. (Jakarta: GIP, 2000), h. 299.

${ }^{29}$ Umer Chapra, Islam and The Economic challenge, h. 295.

${ }^{30}$ Gazi Inayah, al-Iqtishad al-Islami az-Zakah wa ad-dharibah, Dirasah Muqaranah, 1995, Edisi terjemah oleh Zainuddin Adnan dan Nailul Falah, Teori Komprehensif tentang Zakat dan Pajak. (Yogyakarta: Tiara Wacana, 2005), h. 24.

${ }^{31}$ Gusfahmi, Pajak Menurut Syariah, h. 27-30.

${ }^{32}$ Yusuf al-Qaradhawi, Fiqh az-Zakah, (Beirut: Muasssasah al-Risalah, 1973), h. 998.

${ }^{33}$ Gazi Inayah, al-Iqtishad al-Islami az-Zakah wa ad-dharibah, Dirasah Muqaranah, h.

24. 
pengeluaran yang memang diwajibkan atas mereka, pada kondisi dimana baitul mal tidak memiliki uang atau harta. ${ }^{34}$

Dari berbagai definisi tersebut, maka definisi yang dikemukakan Abdul Qadim lebih dekat dan tepat dengan nilai-nilai syariah, karena di dalam definisi yang dikemukakannya terangkum lima unsur penting pajak menurut syariah, yaitu: (1) Diwajibkan oleh Allah SWT; (2) Obyeknya harta; (3) Subyeknya kaum muslim yang kaya; (4) Tujuannya untuk membiayai kebutuhan mereka; (5) Diberlakukan karena adanya kondisi darurat (khusus) yang harus segera diatasi oleh Ulil Amri.

Adapun karakteristik pajak (dharibah) menurut syariat, yang hal ini membedakannya dengan pajak konvensional adalah sebagai berikut; (1) Pajak (dharibah) bersifat temporer, tidak bersifat kontinyu, hanya boleh dipungut ketika di baitul mal tidak ada atau kekurangan harta. Ketika baitul mal sudah terisi kembali, maka kewajiban pajak bisa dihapuskan. Berbeda dengan zakat, yang tetap dipungut, sekalipun tidak ada lagi pihak yang membutuhkan (mustahik). Sedangkan pajak dalam perspektif konvensional adalah selamanya (abadi); (2) Pajak (dharibah) hanya boleh dipungut untuk pembiayaan yang merupakan kewajiban bagi kaum muslimin dan sebatas jumlah yang diperlukan untuk pembiayaan wajib tersebut, tidak boleh lebih. Sedangkan pajak dalam perspektif konvensional ditujukan untuk seluruh warga tanpa membedakan agama; (3) Pajak (dharibah) hanya diambil dari kaum muslim, tidak kaum nonmuslim. Sedangkan teori pajak konvensional tidak membedakan muslim dan non-muslim dengan alasan tidak boleh ada diskriminasi; (4) Pajak (dharibah) hanya dipungut dari kaum muslim yang kaya, tidak dipungut dari selainnya. Sedangkan pajak dalam perspektif konvensional, kadangkala juga dipungut atas orang miskin, seperti PBB; (5) Pajak (dharibah) hanya dipungut sesuai dengan jumlah pembiayaan yang diperlukan, tidak boleh lebih; (6) Pajak (dharibah) dapat dihapus bila sudah tidak diperlukan. Menurut teori pajak konvensional, tidak akan dihapus karena hanya itulah sumber pendapatan.

Pendapat golongan yang mendukung pengharaman pemungutan pajak salah satunya diperkuat oleh atsar yang menyebutkan bahwa Abu Hurairah ra berkata, Maslamah bin Makhlad (gubernur Mesir saat itu) menawarkan tugas penarikan pajak kepada Ruwafi bin Tsabit ra, maka ia berkata: "Sesungguhnya para penarik/pemungut pajak (diazab) di neraka."36

Abu Ja'far Ath Thawawi ${ }^{37}$ berkata bahwa al-Usyr yang telah dihapus kewajibannya oleh Rasulullah Saw atas kaum muslimin adalah pajak yang biasa dipungut oleh kaum jahilliyah. Kemudian beliau menjelaskan bahwa hal ini sangat berbeda dengan kewajiban zakat.

${ }^{34}$ Abdul Qadim, al-Amwal fi daulah al-Khilafah, (Dar al-ilmi lilmalayin, 1988), Edisi terjemah oleh Ahmad dkk, Sistem Keuangan di Negara Khilafah. (Bogor: Pustaka Thariq alIzzah, 2002), h. 138.

\footnotetext{
${ }_{36} \mathrm{http} / / /$ Hayatulislam.net, diakses 20 oktober 2013.

${ }^{36}$ Hadits ini diriwayatkan antara lain oleh Imam Ahmad dan Abu Dawud

${ }^{37}$ Abu Ja'far Ath Thawawi, kitab Syarh Ma'ani Al-Atsar, Jilid 2, h.30-31.
} 
Jika pandangan dan kepercayaan yang mengharamkan pajak dipungut terhadap kaum muslimin tersebut dianut oleh sebagian besar muslim di negaranegara yang masih menerapkan sistem perpajakan dalam mengumpulkan pendapatan negara guna membiayai pengeluaran sektor publik, maka bagi mereka tentu bukan pelanggaran etika atau moral untuk menghindarkan diri dari kewajiban membayar pajak (tax evasion), meskipun mereka juga termasuk orang-orang yang menikmati pelayanan sektor publik yang dibiayai dari pajak yang tidak mereka patuhi tersebut (free rider). Hal ini secara etika kurang tepat karena tidak membayar pajak dengan alasan hukumnya haram namun secara gratis memanfaatkan fasilitas layanan publik.

Robert W. McGee menyatakan bahwa sistem perpajakan dalam Islam adalah sesuatu yang bersifat sukarela (voluntary). Dalam tulisannya, McGee berpendapat bahwa sebagian besar muslimin percaya bahwa tidak ada suatu keharusan moral bagi mereka untuk mematuhi peraturan yang mewajibkan membayar pajak yang dikeluarkan oleh pemerintah. ${ }^{38}$

Dalam fiqih Islam disebutkan bahwa pemerintah memiliki kekuasaan untuk memaksa warga negara membayar pajak, bila jumlah zakat tidak mencukupi untuk menjalankan semua kegiatan pemerintahan. Hak negara untuk meningkatkan sumber daya lewat pajak di samping zakat telah dipertahankan oleh sejumlah fuqaha yang pada prinsipnya mewakili semua mazhab fiqih. Hal ini disebabkan karena pada prinsipnya dana zakat dipergunakan untuk kesejahteraan kaum miskin padahal negara memerlukan sumber dana lain agar dapat melakukan fungsi alokasi, distribusi, dan stabilisasi secara efektif. Hal ini ditegaskan oleh para fuqaha berdasarkan hadits Rasulullah Saw bahwa: Pada hartamu ada kewajiban lain selain zakat. ${ }^{39}$

Argumen ini juga dikuatkan dengan kaidah ushul yang menyatakan bahwa suatu pengorbanan yang lebih kecil dapat dikorbankan untuk menghindari pengorbanan yang lebih besar dan bahwa sesuatu yang apabila suatu kewajiban tidak dapat dilakukan tanpanya, maka sesuatu itu hukumnya wajib. $^{40}$

Abu Yusuf mendukung hak penguasa untuk meningkatkan atau menurunkan pajak menurut kemampuan rakyat. Ulama lain berpendapat bahwa jika sumber-sumber daya negara tidak mencukupi, maka negara harus menghimpun dana dari rakyat untuk memenuhi kepentingan umum. Jika manfaat itu memang dinikmati rakyat, kewajiban mereka membayar ongkosnya. Para khalifah terutama Umar, Ali, dan Umar bin Abdul Aziz diriwayatkan telah menekankan bahwa pajak harus dikumpulkan dengan keadilan dan kemurahan, tidak diperbolehkan melebihi kemampuan rakyat untuk membayar, juga jangan sampai membuat mereka tidak mampu memenuhi kebutuhan pokok sehari-hari. Abu Yusuf berpendapat bahwa sebuah

38 http://papers.ssrn.com/sol3/papers.cfm?abstract_id=461397, diakses 21 Oktober

2013.

39 Hadits riwayat al-Darimiy. Lebih jauh penjelasan hadits ini lihat Yusuf alQaradhawi, Fiqh az-Zakah, vol.2. h. 963

${ }^{40}$ Yusuf al-Qaradhawi, Fiqh az-Zakah, h.4. 
sistem pajak yang baik tidak saja akan meningkatkan penerimaan, tetapi juga meningkatkan pembangunan negara. ${ }^{41}$

Imam Mawardi berpendapat bahwa sistem pajak yang adil akan memberikan keadilan kepada para pembayarnya dan bagi kas penerimaan negara. Terlalu banyak menarik pajak akan menyebabkan ketidakadilan terhadap hak-hak rakyat dan terlalu sedikit berarti tidak adil terhadap kas penerimaan negara. ${ }^{42}$

Melihat tujuan keadilan sosial dan distribusi pendapatan yang merata, maka perkembangan sistem perpajakan tampaknya seirama dengan maqashid syariah. Namun, perlu ditekankan bahwa sesuatu yang sangat relevan bagi kehidupan modern adalah adanya hak negara untuk mengenakan pajak dengan memenuhi rasa keadilan. Sistem pajak harus disesuaikan dengan perubahan tingkat kebutuhan, terutama kebutuhan masal terhadap infrastruktur sosial dan fisik bagi sebuah negara berkembang dan perekonomian modern yang efisien serta komitmen untuk merealisasikan maqashid syariah adalah tujuan-tujuan syariat mengandung semua yang diperlukan manusia untuk merealisasikan kesejahteraan dalam batas-batas syariat. Imam Ghazali, memasukkan semua perkara yang dianggap penting untuk melindungi dan memperkaya keimanan, kehidupan, akal, keturunan, dan harta benda dalam maqashid. Dengan sangat bijaksana Imam Ghazalii meletakkan iman pada urutan pertama dalam daftar maqashid. Iman memberikan suatu filter moral bagi alokasi dan distribusi sumber-sumber daya menurut kehendak persaudaraan dan keadilan sosialekonomi, disamping menyediakan pula suatu sistem pendorong untuk mencapai sasaran seperti pemenuhan kebutuhan dan distribusi pendapatan dan kekayaan yang merata. Sistem tersebut tidak saja harus adil, tetapi juga harus menghasilkan, tanpa berdampak buruk pada dorongan untuk bekerja, tabungan, dan investasi, serta penerimaan yang memadai sehingga memungkinkan negara melaksanakan tanggung jawabnya secara efektif. ${ }^{43}$ yaitu:

Dalam hukum Islam klasik dikenal tiga sistem pemungutan pajak

1. Jizyah atau pajak kepala yang dikenakan kepada kafir zimmi, yaitu non muslim yang hidup di negara/pemerintahan Islam dengan mematuhi peraturan dan perundang-undangan pemerintahan Islam untuk melindungi jiwa, keselamatan, kemerdekaan dan hak-hak asasi mereka. Dalam menghadapi negara non Islam terdapat tiga pilihan yang ditawarkan Islam. (1) masuk Islam, (2) membayar jizyah atau (3) diperangi. Bagi yang masuk Islam mereka aman, tidak diperangi dan tidak ada kewajiban membayar jizyah. Bagi yang tidak mau masuk Islam ada dua pilihan yaitu membayar jizyah atau diperangi.

2. Kharaj, yaitu pajak bumi. Ini berlaku bagi tanah yang diperoleh kaum muslimin lewat peperangan yang kemudian dikembalikan dan digarap

\footnotetext{
${ }^{41}$ Umer Chapra, Islam and The Economic challenge, h.295.

${ }^{42}$ Umer Chapra, Islam and The Economic challenge, h.295-297.

${ }^{43}$ Umer Chapra, Islam and The Economic challenge, h.7-9.
} 
oleh para pemiliknya. Sebagai imbalannya maka pemiliknya mengeluarkan pajak bumi kepada pemerintah Islam.

3. 'Usyur, yaitu pajak perdagangan, atau bea cukai (pajak impor dan ekspor). Mengingat bahwa kebutuhan biaya pembangunan dalam arti luas sangat besar termasuk jalannya roda pemerintahan, maka dibutuhkan dana yang cukup besar yang tidak dapat ditopang oleh zakat semata, Islam membenarkan pemungutan pajak. ${ }^{44}$

Para ulama sejak zaman sahabat, seperti Ibnu Umar, Atha', Ibnu Mas'ud, Ali bin Abi Thalib, Umar bin Khathab dan lainnya, dan juga ulamaulama generasi sesudahnya, berpendapat bahwa disamping zakat masih ada lagi kewajiban muslim terhadap hartanya yang perlu di keluarkan seperti infaq, sedekah maupun pajak.

Dalam hal ini Imam al-Syathibi berpendapat bahwa bila kas negara telah kosong, kebutuhan rakyat dan kemaslahatan umum tidak terpenuhi, roda pemerintahan tidak akan lancar karena kurangnya pendapatan maka pemerintah yang adil dapat memungut pajak pada orang-orang yang mampu selain zakat. Pajak hukumnya mubah atau boleh, karena adanya manfaat besar yang dapat diraih lewat pajak tersebut.

Pemungutan pajak dalam Islam harus terlebih dahulu memperhatikan beberapa hal penting diantaranya bahwa; (1) Pajak yang dikeluarkan harus sesuai dengan kemampuan baik kekayaan maupun sumber penghasilan wajib pajak; (2) Orang yang miskin harus dibebaskan dari membayar pajak; (3) Pajak dapat dilaksanakan jika telah disetujui oleh wakil rakyat; (4) Alokasi penerimaan pajak harus dikeluarkan dengan ketentuan syariah. Dengan demikian maka pajak dapat dikenakan di bawah sistem Islam, selama pendapatan dari pajak tersebut diperlukan untuk pengembangan dan pertahanan negara serta kesejahteraan sosial.

Pajak yang diakui dan dianggap sebagai sistem yang dibenarkan dalam sejarah fiqh Islam harus memenuhi beberapa syarat yaitu:

Pertama; Apabila penerimaan tersebut betul-betul dibutuhkan dan mendesak, sementara tidak ditemukan adanya sumber lain. Pajak itu boleh dipungut apabila negara memang benar-benar membutuhkan dana, sedangkan sumber lain tidak diperoleh. Demikianlah pendapat Syeikh Muhammad Yusuf al-Qaradhawy. Para ulama dan para ahli fatwa hukum Islam menekankan agar memperhatikan syarat ini sejauh mungkin. Sebagian ulama mensyaratkan bolehnya memungut pajak apabila Baitul Mal benar-benar kosong. Para ulama benar-benar sangat hati-hati dalam mewajibkan pajak kepada rakyat, karena khawatir akan membebani rakyat dengan beban yang di luar batas kemampuannya dan keserakahan pengelola pajak dan penguasa dalam mencari kekayaan dengan cara melakukan korupsi hasil pajak.

Kedua; Pemungutan pajak yang adil. Apabila pajak itu benar-benar dibutuhkan dan tidak ada sumber lain yang memadai, maka pemungutan pajak, bukan saja boleh, tapi wajib dengan syarat harus adil dan tidak memberatkan, serta tidak sampai menimbulkan keluhan dari masyarakat. Keadilan dalam

\footnotetext{
${ }^{44}$ P3EI UII Yogyakarta, Ekonomi Islam, h.98.
} 
pemungutan pajak didasarkan kepada pertimbangan ekonomi, sosial, dan kebutuhan yang diperlukan rakyat dan pembangunan. Distribusi hasil pajak juga harus adil, jangan tercemar unsur KKN.

Ketiga; Pajak hendaknya dipergunakan untuk membiayai kepentingan umat, bukan untuk maksiat dan hawa nafsu. Hasil pajak harus digunakan untuk kepentingan umum, bukan untuk kepentingan kelompok, bukan untuk pemuas nafsu para penguasa, kepentingan pribadi, kemewahan keluarga pejabat dan orang-orang dekatnya.

Keempat; Persetujuan para ahli/cendikiawan yang berakhlak. Para penguasa yaitu kepala negara, gubernur atau bupati/walikota dalam pemerintahan di daerah tidak boleh bertindak sendiri untuk mewajibkan pajak dan menentukan besarnya, kecuali setelah dimusyawarahkan dan mendapat persetujuan dari para ahli dan cendikiawan dalam masyarakat serta para wakil rakyat. Selain itu perlu dijaga harmonisasi ketentuan perpajakan di pusat dan daerah, karena pada dasarnya, harta seseorang itu haram diganggu dan harta itu bebas dari berbagai beban dan tanggungan, namun bila ada kebutuhan demi untuk kemaslahatan umum, maka harus dibicarakan dengan para ahli termasuk ulama. Musyawarah adalah unsur pokok dalam masyarakat yang beriman, sebagai perintah langsung dari Allah SWT. Para pejabat pemerintah yang menangani pajak harus mempertimbangkan secara adil, obyektif dan seksama dan matang dalam menetapkan mekanisme pajak. Para wakil rakyat di Dewan Perwakilan Rakyat (DPR) harus menyampaikan dan membawa aspirasi rakyat banyak, bukan hanya memikirkan kepentingan pribadi atau golongan. ${ }^{45}$

Imam Ghazali ${ }^{46}$ menyatakan bahwa memungut uang selain zakat pada rakyat diperbolehkan apabila diperlukan dan kas di Baitul Mal tidak lagi mencukupi untuk kebutuhan negara. Akan tetapi kalau masih ada dana di Baitul Mal, maka tidak boleh. Al Qurtubi mengatakan bahwa ulama sepakat atas bolehnya menarik pungutan selain zakat apabila dibutuhkan. ${ }^{47}$ Ulama madzhab Hanbali juga membolehkan pengumpulan pajak yang mereka sebut dengan al-kalf al-sulthaniyah. Bahkan mereka menganggapnya sebagai jihad dengan harta. Ibnu Taimiyah menganggap pajak yang diambil dari orang kaya merupakan jihad harta. Ulama fiqih kontemporer yang membolehkan pajak antara lain Rashid Ridha, Mahmud Syaltut, Abu Zahrah dan Yusuf Qardhawi.Rashid Ridha ${ }^{48}$ ketika menafsirkan Quran surat al-Nisa ayat 29 antara lain menjelaskan bahwa adanya kewajiban bagi orang kaya untuk memberikan sebagian hartanya dalam bentuk zakat untuk kemaslahatan umum, dan mereka hendaknya dimotivasi untuk mereka mengeluarkan uang di luar zakat untuk kebaikan. Yusuf al-Qaradhawi ${ }^{49}$ menyatakan bahwa negara terkadang tidak mampu untuk memenuhi kebutuhan pembangunannya. Dan

\footnotetext{
${ }^{45}$ Umer Chapra, Islam and The Economic challenge, hal. 295.

${ }^{46}$ Al-Ghazali, al-Mustashfa min 'Ilm al-Ushul, hal.426.

${ }^{47}$ Al-Qurthubi, al-Jami' li Ahkam al-Quran, Jilid 2, h.242.

${ }^{48}$ Rasyid Ridha, Tafsir al-Manar, Jilid 5, h.39.

${ }^{49}$ Yusuf al-Qaradhawi, Fiqh az-Zakah, h.1077.
} 
tidak ada jalan lain selain dengan mengumpulkan pajak.

\section{Aksi Boikot Pajak Menurut Hukum Islam}

Sebagaimana telah dijelaskan bahwa dalam Islam ada dua kelompok yang berbeda pendapat dalam menetapkan hukum pajak. Kelompok pertama berpendapat bahwa pajak bukan merupakan kewajiban yang harus dibayar. Bahkan ada yang sampai berpendapat bahwa pemungutan pajak hukumnya adalah haram. Oleh karena itu, maka menurut kelompok ini umat Islam tidak wajib membayar pajak.

Adapun kelompok lain berpendapat bahwa memungut pajak hukumnya adalah mubah atau sunah selama digunakan untuk kepentingan umum atau hal-hal yang positif. Kelompok kedua menggunakan argumentasi mashlahat mursalah.

Maslahah mursalah secara istilah terdiri dari dua kata yaitu maslahat dan mursalah. Kata maslahat menurut bahasa artinya manfaat dan kata mursalah berarti lepas. Seperti dikemukakan Abdul Wahhab Khallaf berarti sesuatu yang dianggap maslahat namun tidak ada ketegasan hukum untuk merealisasikannya dan tidak ada pula dalil tertentu baik yang mendukung maupun yang menolaknya. ${ }^{50}$

Maslahah mursalah yakni yang dimutlakkan atau maslahah yang bersifat umum, menurut istilah ulama ushul yaitu maslahah dimana syar'i tidak mensyariatkan hukum untuk mewujudkan maslahah itu, juga tidak terdapat dalil yang menunjukan atas pengakuannya atau pembatalannya. Contohnya adalah pada masa sahabat, setelah Rasulullah Saw wafat, mensyariatkan pengadaan penjara, atau mencetak mata uang atau menetapkan (hak milik) tanah pertanian sebagai hasil kemenangan warga sahabat itu sendiri dan ditentukan pajak pengasilannya, atau maslahah-maslahah lain yang muncul karena adanya desakan situasi dan kondisi, kebutuhan atau karena kebaikan, dan belum disyariatkan hukumnya, juga tidak terdapat dalil atau indikasi dari syara' yang mengakui atau membatalkannya. ${ }^{51}$

Ada beberapa syarat agar suatu mashlahat dapat dijadikan dalil, yaitu:

Pertama; Maslahah itu harus hakikat atau benar-benar ada, bukan dugaan, Ahlul halli wal aqdi dan mereka yang mempunyai disiplin ilmu tertentu memandang bahwa pembentukan hukum itu harus didasarkan pada maslahah konkret yang dapat memberikan manfaat untuk manusia dan menolak bahaya dari mereka. Oleh karena itu maka maslahah-maslahah yang bersifat dugaan, sebagaimana yang dipandang sebagian orang dalam sebagian syari at, tidaklah dapat dijadikan hujjah, seperti pemberian hak talak untuk istri, penghapusan masa iddah perempuan yang ditalak suami dan yang lainnya. Pembentukan hukum seperti ini tidak dapat dijadikan hujjah.

Kedua; Maslahah harus bersifat umum dan menyeluruh, tidak khusus untuk orang atau kelompok tertentu saja. Imam-Ghazali memberi contoh tentang maslahah yang bersifat menyeluruh ini dengan suatu contoh yaitu

\footnotetext{
${ }^{50}$ Satria Efendi, Ushul Fiqih, (Jakarta: Kencana, 2005), h. 148-149.

${ }^{51}$ Abdul Wahhab Khalaf,'Ilm Ushul al-Fiqh, (Kairo: Dar al-Kutub, 1942) h. 126.
} 
orang kafir telah membentengi diri dengan sejumlah orang dari kaum muslimin. Apabila kaum muslimin dilarang membunuh mereka demi memelihara kehidupan orang Islam yang membentengi mereka, maka orang kafir akan menang, dan mereka akan memusnahkan kaum muslimin seluruhnya. Dan apabila kaum muslimin memerangi orang Islam yang membentengi orang kafir maka tertolaklah bahaya ini dari seluruh orang Islam yang membentengi orang kafir tersebut. Hal ini dilakukan untuk memelihara kemaslahatan kaum muslimin seluruhnya dengan cara melawan atau memusnahkan musuh-musuh mereka.

Ketiga; Maslahah itu harus sejalan dengan tujuan hukum-hukum yang dituju oleh syari'. Maslahah tersebut harus merupakan maslahah yang telah dijelaskan oleh Syarì. Seandainya tidak ada dalil tertentu yang mengakuinya, maka maslahah tersebut tidak sejalan dengan apa yang telah dituju oleh Islam. Bahkan tidak dapat disebut maslahah. ${ }^{52}$

Apabila pajak itu merupakan suatu bentuk kemaslahatan atau kebaikan yang telah memenuhi tiga kriteria tersebut maka pajak menjadi suatu kewajiban yang harus dilaksanakan. Memboikot pajak yang jelas tujuannya untuk kebaikan atau kemaslahatan umum berarti juga merupakan suatu tindakan yang tidak sesuai dengan konsep maslahat mursalah tersebut.

Selain itu, aksi boikot pajak dalam literatur fiqih dapat dianalisis dengan menggunakan teori sadd al-dzariah. Terdapat berbagai definisi yang dikemukakan oleh ulama dalam memberikan pengertian sadd al-dzariah. Menurut al-Qurtubi, sadd al-dzariah ialah perkara yang pada asalnya tidak dilarang untuk dilakukan, namun karena perkara itu mengandung unsur-unsur yang akan membawa kepada kerusakan, maka ia dilarang untuk dilakukan. ${ }^{53}$

Al-Syatibi berpendapat bahwa sadd al-dzariah adalah menggunakan maslahah sebagai cara untuk menghalang mafsadah. ${ }^{54}$ Menurut Muhammad Hisham al-Burhani, sadd al-dzariah ialah suatu perkara yang tidak dilarang pada asalnya, tetapi ia menjadi dilarang jika terdapat unsur-unsur yang akan membawa kepada kerusakan dan keburukan. ${ }^{55}$ Al-Qarrafi menegaskan bahwa sadd al-dzari'ah ialah suatu langkah pencegahan yang wajib dilakukan jika terdapat perkara- perkara yang mendorong ke arah kerusakan. Hal ini berbeda sekiranya al-dhari'ah mendorong ke arah kebaikan maka ia dinamakan fath aldzariah. ${ }^{56}$

Imam al-Syathibi membagi al-dzariah menjadi 4 bagian, yaitu:

Pertama; Perbuatan yang secara hukum dibolehkan (mubah) akan tetapi pasti akan mendatangkan kerusakan atau sesuatu yang diharamkan.

52 Muhammad Mushthafa Syalabiy, Madkhal fi al-Ta'srif bi al-Fiqh al-Islamiy wa Qawa'id al-Milkiyyah wa al-'Uqud fihi, (Bairut: Dar an-Nahdlah al-'Arabiyah, 1985), h.256.

${ }^{53}$ Muhammad ibn Ahmad Al- Qurtubi. t.th. al- Jami li ahkam al- Quran. (Qahirah: alHay ah al-Misriyyah al- ammah li al- Kitab, t.th), Jilid 2, h.57-58.

${ }^{54}$ Ibrahim ibn Musa Al-Shatibi, al-Muwafaqat fi ushul al-syari ah, (Beirut: Dar al-Fikr, t.th), h.144.

${ }^{55}$ Muhammad Hisham Al-Burhani, Sadd al- dhara'i fi al-syariah al-Islamiyyah, (Damsyik: Dar al-Fikr, 1985), h.80.

${ }^{56}$ Ahmad bin Idris Al- Qarafi, al- Furuq, (Beirut: Dar al- Ma'rifah, t.th), h.42. 
Ulama sepakat bahwa perbuatan tersebut hukumnya menjadi terlarang karena akan menimbulkan madharat atau kerusakan.

Kedua; Perbuatan yang mendatangkan sedikit mafsadah. Perbuatan ini hukum asalnya adalah mubah dan sedikit kemungkinan menimbulkan madharat atau kerusakan. Manfaat dari perbuatan ini lebih besar daripada madharat atau kerusakan yang mungkin timbul sebagai akibat sampingan atau yang tidak diperkirakan. Ulama sepakat bahwa perbuatan ini hukumnya adalah tetap sama dengan hukum asalnya yaitu mubah.

Ketiga; Perbuatan yang kebiasaannya akan membawa pada mafsadah atau madharat. Disengaja atau tidak maka perbuatan itu akan melahirkan kerusakan. Ulama menetapkan bahwa perbuatan seperti ini dilarang.

Keempat; Perbuatan yang seringkali membawa kepada mafsadah, namun ia tidak menjadi kebiasaan atau suatu kepastian. Dalam hal ini menurut Imam Abu Hanifah dan al-Syafi'i hukumnya tetap mubah karena kemungkinan timbul kerusakannya tidak sampai pada tingkat yang meyakinkan atau sangkaan kuat. Namun menurut Imam Malik dan Imam Ahmad perbuatan seperti itu hukumnya haram. ${ }^{57}$

Apabila memakai teori sadd al-dzariah ini maka aksi boikot pajak adalah harus dikaji lebih lanjut termasuk kategori yang mana, apakah kategori satu, dua, tiga atau empat. Apabila peluang korupsi pajak sudah pasti maka aksi boikot pajak dapat dibenarkan. Namun apabila peluang uang pajak dikorupsinya kecil, maka aksi boikot pajak tidak dibenarkan. Penulis berpendapat bahwa uang pembayaran pajak di Indonesia masih digunakan secara yakin untuk hal-hal yang bermanfaat bagi kepentingan umum. Oleh karena itu, maka aksi boikot pajak masih belum terlalu relevan untuk konteks Indonesia.

\section{Penutup}

Berdasarkan pemaparan di atas, maka dapat disimpulkan hal-hal sebagai berikut: (1) Ulama berbeda pendapat dalam menentukan hukum pajak. Sebagian berpendapat bahwa pajak bukan merupakan suatu kewajiban bagi umat Islam, karena yang diwajibkan hanyalah zakat. Bahkan ada yang 'ekstrim' berpendapat bahwa negara haram memungut pajak kepada warga negaranya. Sebagian yang lain berpendapat bahwa pajak hukumnya mubah atau sunah, selama pajak tersebut digunakan untuk hal-hal baik yang sesuai dengan koridor syariat. Bahkan bisa jadi hukum membayar pajak menjadi wajib apabila pajak tersebut benar-benar sangat dibutuhkan untuk kemaslahatan umum; (2) Sejak zaman Rasulullah Saw dikenal adanya berbagai pungutan selain zakat, dimana harta benda yang dikumpulkan didistribusikan untuk berbagai keperluan dan kebutuhan masyarakat yang tidak tercover oleh dana zakat; (3) Di Indonesia, pajak yang dipungut dari masyarakat digunakan untuk pembangunan. Bahkan sebagian besar sumber pemasukan negara berasal dari pajak. Oleh karena itu, menurut hemat penulis, hukum membayar pajak adalah sunah, bahkan pada

${ }^{57}$ Amir Syaifudin, Usul fiqh, h.121. 
saat-saat tertentu menjadi wajib; (4) Walaupun ada beberapa kasus korupsi yang dilakukan oleh 'oknum' pegawai pajak atau pejabat yang berwenang, namun hal ini bukan merupakan kebijakan negara, sehingga hal ini tidak mempengaruhi hukum membayar zakat. Oleh karena itu, maka aksi boikot pajak di Indonesia untuk saat ini merupakan suatu tindakan yang kurang relevan karena akan menyebabkan terhambatnya pembangunan atau operasional kegiatan pemerintah; (5) Menurut hukum positif di Indonesia tindakan tidak membayar yang dilakukan secara sengaja, termasuk aksi boikot pajak, merupakan suatu bentuk kejahatan pidana yang akan mendapatkan sanksi.

\section{Pustaka Acuan}

Al- Qurtubi, Muhammad ibn Ahmad. al-Jami li ahkam al-Quran. Qahirah: alHay ah al- Misriyyah al-'Ammah li al-Kitab. t.th.

Al-Burhani, Muhammad Hisham. Sadd al-dhara'i fi al-syariah al-Islamiyyah. Damsyik: Dar al-Fikr. 1985.

Al-Ghazali. al-Mustashfa min 'Ilm al-Ushul.

Al-Qaradhawi, Yusuf. Fiqh al-Zakah. Beirut: Muasssasah al-Risalah. 1973.

Al-Qarrafi, Ahmad bin Idris. al- Furuq. Beirut: Dar al- Ma'rifah. t.th.

Al-Qurthubi. al-Jami' li Ahkam al-Quran.

Al-Syatibi, Ibrahim ibn Musa. al- Muwafaqat fi ushul al-syariah. Beirut: Dar alFikr. t.th.

Ash-Shiddieqy, Hasbi. Filsafat Hukum Islam. Semarang: PT. Pustaka Rizqi Putra. 2001.

Chapra, Umer. Islam and The Economic challenge. Herndon: IIIT. 1995.

Efendi, Satria. Ushul Fiqih. Jakarta: Kencana. 2005.

Gusfahmi. Pajak Menurut Syariah. Jakarta: Rajawali Press. 2007.

Ilyas, Wirawan B. dan Richard Burton. Hukum Pajak. Jakarta: Salemba Empat. edisi 3. 2007.

Inayah, Gazi. al-Iqtishad al-Islami al-Zakah wa al-Dharibah; Dirasah Muqaranah. 1995. Edisi terjemah oleh Zainuddin Adnan dan Nailul Falah. Teori Komprehensif tentang Zakat dan Pajak. Yogyakarta: Tiara Wacana. 2005.

James, Simon and Christopher Nobes. The Economics of Taxation. Edinburgh: Pearson Educatioan Limited. ed. 7. 2003.

Karim, Adiwarman Azwar. Sejarah Pemikiran Ekonomi Islam. Jakarta: The International Institue of Islamic Thought Indonesia IIIT. 2001.

Khalaf, Abdul Wahhab.'Ilm Ushul al-Fiqh. Kairo: Dar al-Kutub. 1942. Majalah Prisma. LP3ES. 1985.

P3EI UII Yogyakarta. Ekonomi Islam. Jakarta: Rajawali Press. 2008.

Prakosa, Kesit Bambang. Hukum Pajak. Yogyakarta: EKONISIA. 2005.

Qadim, Abdul. al-Amwal fi daulah al-Khilafah. Dar al-ilmi lilmalayin. 1988. Edisi terjemah oleh Ahmad dkk. Sistem Keuangan di Negara Khilafah. Bogor: Pustaka Thariq al-Izzah. 2002.

Ridha, Rasyid. Tafsir al-Manar. 
Schacht, Joseph. An Introduction to Islamic Law. Oxford: Clarendon Press. 1993.

Syarifuddin, Amir. "Pengertian dan Sumber Hukum Islam". dalam Filsafat Hukum Islam. Jakarta; Departemen Agama. 1992.

\section{Website:}

http://id.wikipedia.org/wiki/Pajak.

http://www.pajak.go.id.

http://www.republika.co.id.

http://www.nu.or.id.

http://www.pajakonline.com

http://Hayatulislam.net.

http://papers.ssrn.com 